\title{
Optimization of wind solar and battery hybrid renewable system using backtrack search algorithm
}

\author{
Ingudam Chitrasen Meitei, Rajen Pudur
}

Department of Electrical Engineering, National Institute of Technology, Itanagar, India

\begin{tabular}{l} 
Article Info \\
\hline Article history: \\
Received Mar 7, 2021 \\
Revised Oct 13, 2021 \\
Accepted Oct 28, 2021 \\
\hline
\end{tabular}

\section{Keywords:}

HOMER

Optimization

Renewable hybrid system backtrack search algorithm

\begin{abstract}
Penetration of renewable sources to the grid is always a problem for electrical engineers, apart from reliability and efficiency, cost optimization is also a big concern among them. Wind, solar and battery hybrid combinations (WSB-HPS) are also very common among hybrid systems, but this WSBHPS combines wind and solar energy power generation reduces the charge and discharge time of the battery. Therefore, this system improves the reliability of the power supply by fully utilizing the wind and solar power generation and improves the charging and discharging state of the battery and hence reduces the whole cost as the investment in battery is reduced. backtrack search algorithm (BSA) is the highly efficient and powerful algorithm to solve combinatorial optimization problems. In this paper an attempt is made to optimize the hybrid combination using BSA in the matrix laboratory (MATLAB) environment and comparable study is made using HOMER. A complete optimised data is generated for a particular area in Manipur and reduced cost is suggested.
\end{abstract}

This is an open access article under the CC BY-SA license.

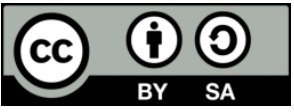

\section{Corresponding Author:}

Ingudam Chitrasen Meitei

Department of Electrical Engineering, National Institute of Technology

Itanagar, Arunachal Pradesh

Email: alwayschitrasen@gmail.com

\section{INTRODUCTION}

With the discovery of electricity, our life has become safer and easier instead of using oil and gas lamps, which were flammable and dangerous. Ever since the introduction of electricity, people were more eager to harness the power for a variety of purposes ranging from lighting their homes to electric cars in order to make their lives convenient [1], [2]. It helps in the development of a nation and it is the most important source of energy utilization process. Electricity is the foundation of human growth and advancement [3], [4].

However, there are still some major challenges faced by the generating stations when transmitting the generated electricity. Corona effect, radio interference and Ferranti effect are some of the common challenges faced during transmission. New technologies like high-voltage, direct current (HVDC) and facts have already been introduced in the power market for more efficient transmission of electricity [5], [6]. Converters used between the bus bars are also effective.

But the effort in transmitting power from generating stations to end users in hilly regions is always difficult because there is an increase in cost due to difficult terrain. Hence this hybrid power system consisting of wind, battery and solar is introduced so that it can be installed near the end users. This helps in the reduction of transmission cost as well as the dependency on conventional energy sources are also decreased [7], [8]. Further cost reduction is expected and consequent climate change mitigation. 
The schematic diagram of the hybrid renewable energy systems (HRES) model is shown in Figure 1. The figure shows solar and wind energy supplying electricity to the load. Battery is also used for energy storage. Renewable energy resources are abundantly available in nature although it depends on the weather conditions and locations whether these energies are accessible or not. Hybrid system employing renewable resources that combines one or more resources along with a battery is more promising and has higher reliability than the conventional energy source [9], [10]. In remote and isolated places, this hybrid power system is more preferable [11]. At the same time, depletion of exhaustible non-renewable energy resources is kept in check. The output of photovoltaic (PV) and power generated from wind turbines usually fluctuate due to the irregularities and unplanned nature of solar energy and wind energy and so it requires a huge capacity of energy storage systems to meet the required load demand in standalone mode and therefore depends on utility grid. This issue can be overcome by the mutual combination of solar and wind characteristics by taking into account the complementary characteristics of solar and wind energy [12], [13]. An appropriate solar, battery and wind energy system can maximize the reliability of power supply and reduces the cost of the system [14]. In a grid connected hybrid system, grid is kept as a back-up power system for fulfilling the required load demand [15]-[18]. In this paper, astudy was conducted between two techniques using HOMER and backtrack search algorithm (BSA) f in matrix laboratory (MATLAB) environment (R2018a version, 40832900) to find the best result and reduced cost is suggested for hybrid renewable energy system for powering the National Institute of Technology Manipur and Shija Hospitals, Manipur.

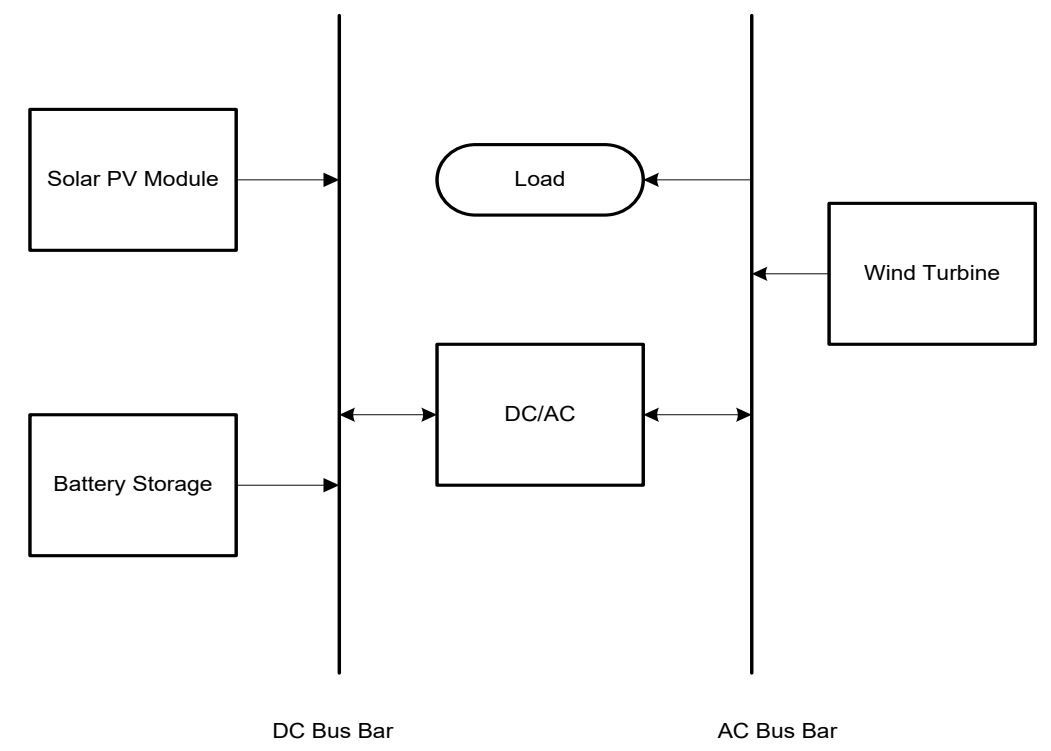

Figure 1. Schematic layout of the hybrid system

\section{METHODOLOGY AND NUMERICAL FORMULATION}

The process of optimization is implemented using an algorithm known as a modified BSA. BSA is a newly developed progressive algorithm and it has a particular mechanism to generate trial individuals enabling it to perform calculation of numerical optimization problems very fast [19]-[22]. An American mathematician D.H. Lehmar was the first to introduce the term "backtrack" in the 1950s.

\subsection{Mathematical modeling of the required components}

The power output for the photovoltaic arrays is given by,

$$
\mathrm{P}_{\mathrm{pv}}=\mathrm{f}_{\mathrm{pv}} \mathrm{P}_{\mathrm{pv} \_\mathrm{r}} \frac{\mathrm{G}}{\mathrm{GSTC}_{\mathrm{STC}}}\left[1+\alpha_{\mathrm{T}}\left(\mathrm{T}-\mathrm{T}_{\mathrm{STC}}\right)\right]
$$

where $\mathrm{P}_{\mathrm{pv} \_\mathrm{r}}=$ rated power output of the PV module,

$\mathrm{f}_{\mathrm{pv}}=$ de-rating factor (loss and shading considered)

$\mathrm{G}_{\mathrm{STC}}=$ standard solar radiation on PV

$\mathrm{T}_{\mathrm{STC}}=$ standard temperature on $\mathrm{PV}$

$\mathrm{T}$ and $\mathrm{G}=$ real time temperature and solar radiation $\alpha_{\mathrm{T}}=$ temperature coefficient 
The curve for the generated wind power from the wind turbine can be represented by (2),

$$
\mathrm{P}_{\mathrm{wt}}=\left\{\begin{array}{c}
0 \mathrm{v}_{\mathrm{w}}<\mathrm{V}_{\mathrm{ci}} \text { or } \mathrm{v}_{\mathrm{w}}>\mathrm{V}_{\mathrm{co}} \\
\mathrm{P}_{\mathrm{wt} \_\mathrm{r}} \frac{\mathrm{v}_{\mathrm{w}}-\mathrm{V}_{\mathrm{ci}}}{\mathrm{V}_{\mathrm{r}}-\mathrm{V}_{\mathrm{ci}}} \mathrm{V}_{\mathrm{ci}} \leq \mathrm{v}_{\mathrm{w}} \leq \mathrm{V} \\
\mathrm{P}_{\mathrm{wt}_{-} \mathrm{r}} \mathrm{V}_{\mathrm{r}} \leq \mathrm{v}_{\mathrm{w}} \leq \mathrm{V}_{\mathrm{co}}
\end{array}\right.
$$

where $\mathrm{P}_{\mathrm{wt} \_\mathrm{r}}=$ rated power output of wind turbine,

$\mathrm{V}_{\mathrm{W}}=$ wind speed

$\mathrm{V}_{\mathrm{r}}=$ rated wind speed

$\mathrm{V}_{\mathrm{ci}}=$ cut-in speed

$\mathrm{V}_{\text {co }}=$ cut-out speed

The terminal voltage of the battery is given by,

$$
\mathrm{V}_{\mathrm{bs}}=\mathrm{E}_{\mathrm{bs}}-\mathrm{I}_{\mathrm{dch}} \mathrm{R}_{0}
$$

where $\mathrm{E}_{\mathrm{bs}}=$ effective internal voltage,

$\mathrm{I}_{\mathrm{dch}}=$ discharge current

$\mathrm{R}_{0}=$ internal resistance

The effective internal voltage is given by,

$$
\mathrm{E}_{\mathrm{bs}}=\mathrm{E}_{\mathrm{o}}+\mathrm{AX}+\mathrm{CX} /(\mathrm{D}-\mathrm{X})
$$

where $E_{o}=$ internal battery voltage at fully charged/discharged state,

$A=$ variation in initial linear internal battery voltage with charging state

$\mathrm{D}, \mathrm{C}=$ increase/decrease in battery voltage during progressive charging/discharging

$\mathrm{X}=$ maximum normalized capacity at specified current

\subsection{Strategy of energy management}

Considering the hybrid power system, when the total power generated by the system is less than the load demand, the battery will be discharged and is given by (5). And when the total power generated is more than the load, the battery will be charged and is given by (6). The power flow expression is given by,

$$
\begin{aligned}
& P_{L}(t)=P_{w t}(t)+P_{p v}(t)+P_{b s_{-} d c h}(t) \\
& P_{L}(t)=P_{w t}(t)+P_{p v}(t)-P_{b s_{-} c h}(t)
\end{aligned}
$$

\subsection{Strategy of energy management}

The reliability of the power supply is given by (7),

$$
\operatorname{LPSP}=\frac{\sum_{\mathrm{i}=1}^{\mathrm{N}}\left[\mathrm{P}_{\mathrm{L}}\left(\mathrm{t}_{\mathrm{i}}\right)-\left(\mathrm{P}_{\mathrm{wt}}\left(\mathrm{t}_{\mathrm{i}}\right)+\mathrm{P}_{\mathrm{pv}}\left(\mathrm{t}_{\mathrm{i}}\right)+\mathrm{P}_{\mathrm{bs} \_\mathrm{dch}}\left(\mathrm{t}_{\mathrm{i}}\right)\right)\right]}{\sum_{\mathrm{i}=1}^{\mathrm{N}} \mathrm{P}_{\mathrm{L}}\left(\mathrm{t}_{\mathrm{i}}\right)}
$$

where $t_{i} \sim t_{N}=$ operating time of the system. If the scope for load satisfaction (LPSP) is 0 , then it indicates that the load demand is always met by the system. And if it is 1 , then the load is never satisfied.

The rate of relative fluctuation is given by,

$$
\mathrm{D}_{\mathrm{L}}=\frac{1}{\overline{\mathrm{P}}_{\mathrm{L}}} \sqrt{\frac{1}{\mathrm{~N}} \sum_{\mathrm{i}=1}^{\mathrm{N}}\left(\mathrm{P}_{\mathrm{wt}}\left(\mathrm{t}_{\mathrm{i}}\right)+\mathrm{P}_{\mathrm{pv}}\left(\mathrm{t}_{\mathrm{i}}\right)-\mathrm{P}_{\mathrm{L}}\left(\mathrm{t}_{\mathrm{i}}\right)\right)^{2}}
$$

where $\overline{\mathrm{P}}_{\mathrm{L}}=$ average power of load. A lower value of $\mathrm{D}_{\mathrm{L}}$ implies that complementary characteristics of solar and wind is utilized efficiently.

\subsection{Required constraints}

The maximum number of wind generator turbines, solar panels and battery respectively are given by,

$$
\mathrm{N}_{\mathrm{wt}} \leq\left[\frac{\mathrm{L}}{(6-10) \mathrm{d}}+1\right] \cdot\left[\frac{\mathrm{W}}{(3-5) \mathrm{d}}+1\right]
$$

where $\mathrm{L}$ and $\mathrm{W}=$ length and width for the region, $\mathrm{d}=$ rotor diameter

$$
\mathrm{N}_{\mathrm{pv}} \leq\left[\mathrm{S}_{2} / \mathrm{S}_{\mathrm{pv}}\right] \cdot \alpha_{\mathrm{pv}}
$$


where S2 = given installation area for solar PV panel,

$\mathrm{S}_{\mathrm{pv}}=$ area of one PV unit

$\alpha_{\mathrm{pv}}=$ coefficient for possible shadow area

$$
\mathrm{N}_{\mathrm{bs}} \leq\left[\mathrm{S}_{3} / \mathrm{S}_{\mathrm{bs}}\right]
$$

where S2 = given installation area for battery,

$\mathrm{S}_{\mathrm{bs}}=$ area of single battery

The minimum number of wind turbines, solar panels and battery respectively are given by,

$$
\mathrm{N}_{\text {wt }} \geq \int_{\mathrm{tm} 2}^{\mathrm{tm} 3} \mathrm{P}_{\mathrm{L}}(\mathrm{t}) \mathrm{dt} / \int_{\mathrm{tm} 2}^{\mathrm{tm} 3} \mathrm{P}_{\mathrm{wt}}(\mathrm{t}) \mathrm{dt}
$$

where $\operatorname{tm} 2-\operatorname{tm} 3=$ effective operating time of wind turbine during night,

$$
\mathrm{N}_{\mathrm{pv}} \geq \int_{\mathrm{tm} 0}^{\mathrm{tm} 1} \mathrm{P}_{\mathrm{L}}(\mathrm{t}) \mathrm{dt} / \int_{\mathrm{tm} 0}^{\mathrm{tm} 1} \mathrm{P}_{\mathrm{pv}}(\mathrm{t}) \mathrm{dt}
$$

where tm0-tm 1 = effective operating time of PV during day,

$$
\mathrm{N}_{\mathrm{bs}} \geq \frac{\lambda \cdot \mathrm{W}_{\mathrm{Ld}}}{\eta \cdot \mathrm{C}_{\mathrm{bs}} \cdot \mathrm{V}_{\mathrm{bs}} \cdot \mathrm{DOD}_{\max }}
$$

where $\mathrm{W}_{\mathrm{LD}}=$ energy consumed everyday by load,

$\mathrm{Vbs}, \mathrm{Vbs}=$ voltage and capacity of single battery

$\eta=$ battery discharging efficiency

The reserved operating capacity is given by,

$$
\sum \mathrm{P}_{\mathrm{DG}} \geq(1+\mu \%) \mathrm{P}_{\mathrm{L}}
$$

where $\mathrm{P}_{\mathrm{DG}}=$ total power output of the distributed generation, $\mu=$ operating reserve ratio $(10 \%)$

The charging and discharging constraints of the battery is given by,

$$
\begin{aligned}
& \mathrm{SOC}_{\min } \leq \mathrm{SOC} \leq \mathrm{SOC}_{\max } \\
& \mathrm{r}_{\mathrm{ch}} \leq \mathrm{r}_{\mathrm{ch} \_\mathrm{R}}, \mathrm{r}_{\mathrm{dch}} \leq \mathrm{r}_{\mathrm{dch} \_\mathrm{R}}
\end{aligned}
$$

where $r_{c h}, r_{d c h}=$ charging and discharging rate,

$r_{c_{\_} R}, r_{d_{c h} R}=$ limited charging and discharging rate

$$
\mathrm{I}_{\text {ch }} \leq \mathrm{I}_{\text {chmax }}, \mathrm{I}_{\mathrm{dch}} \leq \mathrm{I}_{\mathrm{dchmax}}
$$

where $\mathrm{I}_{\mathrm{ch}}, \mathrm{I}_{\mathrm{dch}}=$ charging and discharging current,

$\mathrm{I}_{\text {chmax }}, \mathrm{I}_{\mathrm{dchmax}}=$ maximum charging and discharging current

$$
\begin{aligned}
& 0 \leq \mathrm{P}_{\text {bs_ch }} \leq \mathrm{P}_{\text {bs_chmax }_{-}} \\
& 0 \leq \mathrm{P}_{\text {bs_dch }} \leq \mathrm{P}_{\text {bs_dchmax }}
\end{aligned}
$$

where $\mathrm{P}_{\mathrm{bs} \_c h}, \mathrm{P}_{\mathrm{bs} \_\mathrm{dch}}$, = charging and discharging power,

$\mathrm{P}_{\mathrm{bs} \_ \text {chmax }}, \mathrm{P}_{\mathrm{bs} \_d c h m a x}=$ maximum charge and discharge power [23], [24],

$$
\mathrm{N}_{\mathrm{C}} \leq \mathrm{N}_{\mathrm{Cmax}}
$$

where $\mathrm{N}_{\mathrm{C}}, \mathrm{N}_{\mathrm{Cmax}}=$ charging/discharging cycle of battery and its limited value,

\subsection{Total cost}

Initial cost of the system $\mathrm{Ci}=(\mathrm{NpvCpv}+\mathrm{NwtCwt}+\mathrm{NbsCbs}) \mathrm{fcr}$

where $\mathrm{Cpv}$,Cwt, Cbs=cost of PV panels, wind turbine and battery, $\mathrm{fcr}=$ capital recovery factor

Operating and maintenance cost, 


$$
\mathrm{C}_{\mathrm{OM}}=\mathrm{C}_{\mathrm{pv} \_\mathrm{OM}} \mathrm{t}_{\mathrm{PV}}+\mathrm{C}_{\mathrm{wt} \mathrm{OM}_{\mathrm{O}}} \mathrm{t}_{\mathrm{wt}}+\mathrm{C}_{\mathrm{bs} \_\mathrm{OM}} \mathrm{t}_{\mathrm{bs}}
$$

where $\mathrm{C}_{\text {pv_om }}, \mathrm{C}_{\mathrm{wt} \_\mathrm{OM}}, \mathrm{C}_{\mathrm{bs}_{-} \mathrm{OM}}=$ operating and maintenance cost of PV panels, wind turbine and battery $t_{\mathrm{PV}}, \mathrm{t}_{\mathrm{wt}}, \mathrm{t}_{\mathrm{bs}}=$ operating time of PV panels, wind turbine and battery,

$$
\text { Replacement Cost } \mathrm{C}_{\mathrm{R}}=\mathrm{C}_{\mathrm{pv}_{\_} \mathrm{R}}+\mathrm{C}_{\mathrm{wt} \_\mathrm{R}}+\mathrm{C}_{\mathrm{bs} \_\mathrm{R}}
$$

where $\mathrm{C}_{\mathrm{pv}_{-} \mathrm{R}}, \mathrm{C}_{\mathrm{wt} \_\mathrm{R}}, \mathrm{C}_{\mathrm{bs} \_\mathrm{R}}=$ replacement cost of PV panels, wind turbine and battery,

\subsection{Objective function}

Reducing the total cost of the hybrid power system is regarded as the objective function. It is given by,

$$
\min \mathrm{f}=\min \left(\mathrm{C}_{\mathrm{i}}+\mathrm{C}_{\mathrm{OM}}+\mathrm{C}_{\mathrm{R}}-\mathrm{C}_{\mathrm{gs}}+\mathrm{C}_{\mathrm{gp}}+\mathrm{C}_{\mathrm{pc}}\right)
$$

where $\mathrm{C}_{\mathrm{gp}}, \mathrm{C}_{\mathrm{gs}}=$ Cost of purchasing power from the grid and selling power to the grid, $\mathrm{C}_{\mathrm{pc}}=$ penalty cost. The flowchart of the suggested method is shown in Figure 2. The flowchart explains the step-by-step procedure of the optimization process. The various data collected are used and the final net total cost is found out.

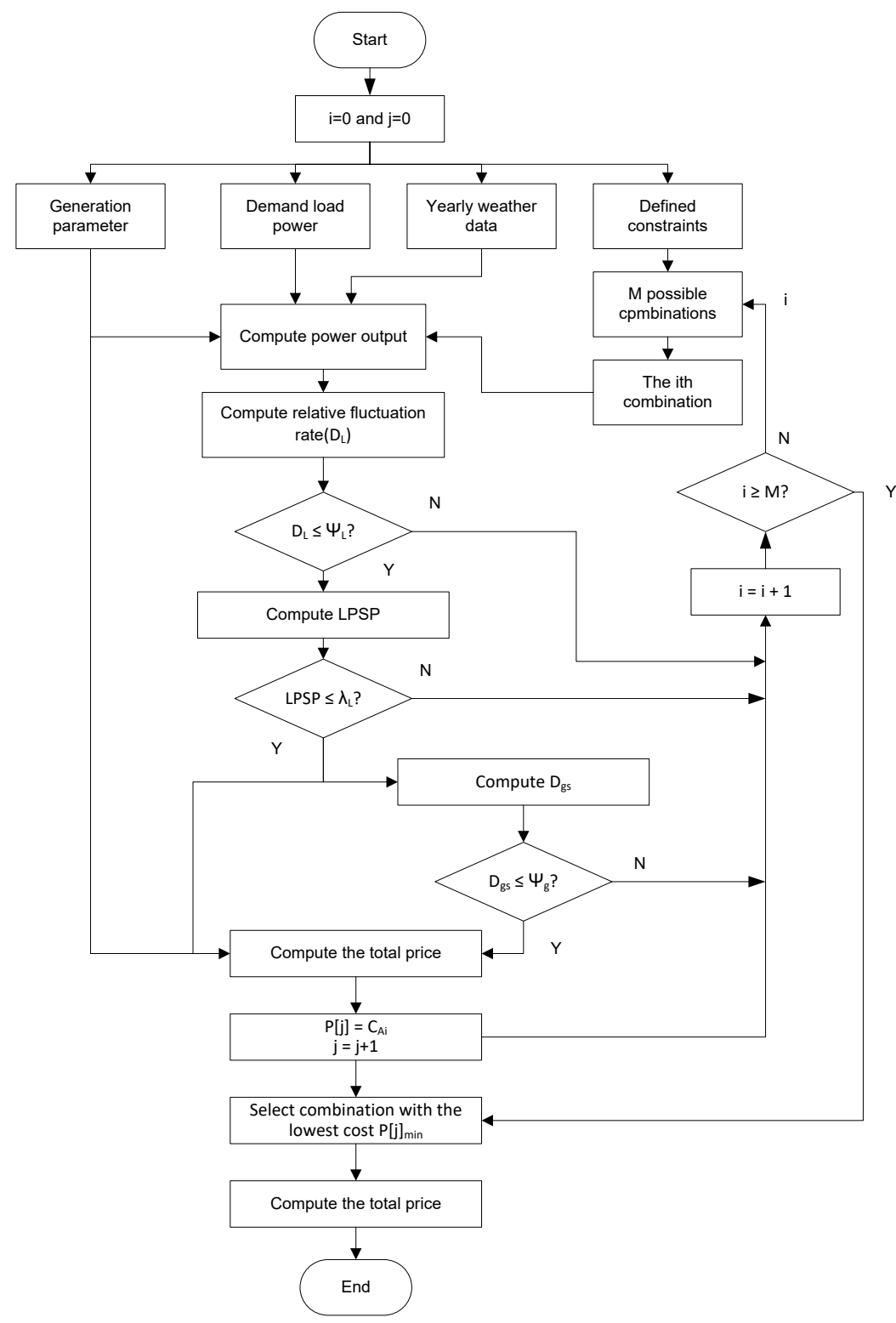

Figure 2. Flowchart of the proposed method 


\section{SITE UNDER STUDY AND ITS LOAD ESTIMATION}

The suggested model is presented for powering the National Institute of Technology Manipur and Shija Hospitals, Manipur. These two premises are located adjacent to each other at the same location in Manipur. The former is an educational institute of national importance and the latter is a renowned hospital of the state. The selected site is situated at $24^{\circ} 50^{\prime} 33.20^{\prime \prime} \mathrm{N}$ latitude and $93^{\circ} 55^{\prime} 28.82^{\prime \prime}$ 'E longitude [25]. The power consumed by the institute and the hospital are segregated and listed in the Table 1 . The total load demand is also noted.

Table 1. Details of load profile

\begin{tabular}{cccc}
\hline Sl. No & Load Considered & Daily Load Demand & Peak Load Demand \\
\hline Load 1 & NIT Manipur & $1210 \mathrm{~kW} /$ day & $215.38 \mathrm{~kW}$ \\
Load 2 & Shija Hospitals & $2639 \mathrm{~kW} /$ day & $402.04 \mathrm{~kW}$ \\
Total Average Load Demand & \multicolumn{2}{c}{$3849 \mathrm{~kW} /$ day } \\
\hline
\end{tabular}

In this paper the required data of electrical load for both the institute and the hospital are collected from the Manipur state power distribution company limited (MSPDCL). Here, Figure 3 presents the hourly load profile for National Institute of Technology (NIT) Manipur, the highest peak demands can be seen during 08001700 hours. And Figure 4 presents the hourly load profile for Shija Hospitals, and the highest peak demands can be seen during 1100-1300 hours.

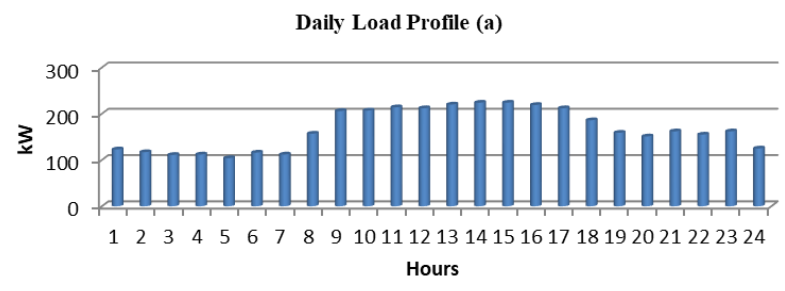

Figure 3. Average hourly load profile of NIT Manipur



Figure 4. Average hourly load profile of Shija Hospital

\section{RESOURCES AND ELEMENTS}

The resources and elements that are viewed for the optimization procedure are listed in the Table 2. The resources used are wind turbine, Solar PV and battery. The purpose of battery is to utilize it during low energy production from the sources. Various cost of the components are also listed below.

Table 2. Details of the components used

\begin{tabular}{|c|c|c|c|c|c|c|c|}
\hline Source & Company & Lifetime & Type & Rating & $\begin{array}{c}\text { Capital } \\
\text { Cost }\end{array}$ & $\begin{array}{c}\text { Replacement } \\
\text { Cost }\end{array}$ & $\begin{array}{c}\text { O\&M } \\
\text { Cost }\end{array}$ \\
\hline Wind & J.D. Engineering & 20 years & 3-Phase Permanent & $48 \mathrm{~V}$ and Rated & Rs. 50,000 & Rs. 90,000 & Rs. 10,000 \\
\hline Turbine & Works & & Magnet & $\mathrm{r} 1 \mathrm{~kW}$ & $/ \mathrm{kW}$ & $/ \mathrm{kW}$ & \\
\hline $\begin{array}{l}\text { Solar PV } \\
\text { Module }\end{array}$ & Loom Solar & 25 years & Mono Crystalline & $\begin{array}{l}340 \mathrm{~W} \text {, Derating } \\
\text { factor of } 80 \%\end{array}$ & $\begin{array}{l}\text { Rs. } 12,400 \\
\text { /unit }\end{array}$ & $\begin{array}{l}\text { Rs. } 12,400 \\
\text { /unit }\end{array}$ & $\begin{array}{l}\text { Rs. } 4,000 \\
\text { /unit }\end{array}$ \\
\hline Battery & $\begin{array}{l}\text { Amaron HCV } \\
620 \mathrm{D} 31 \mathrm{R}\end{array}$ & 8 years & Lead Acid Battery & $12 \mathrm{~V}, 80 \mathrm{Ah}$ & $\begin{array}{c}\text { Rs. } 6,300 \\
\text { /unit }\end{array}$ & Rs. 6,300/unit & $\begin{array}{l}\text { Rs. } 1000 \\
\text { /battery }\end{array}$ \\
\hline
\end{tabular}




\subsection{Solar energy and wind energy resources}

The solar energy radiation data of the selected location which is at $24^{\circ} 50^{\prime} 33.20^{\prime \prime} \mathrm{N}$ latitude and 93 $55^{\prime} 28.82^{\prime}$ 'E longitude is obtained from the National Aeronautics and Space Administration (NASA) surface meteorology and database of solar energy. The obtained data of solar radiation is shown in Figure 5. The clearness index measures the clearness of the sky and it is dimensionless. It is defined as the fraction of the solar radiation that passes through the atmosphere of the earth and hits the surface of earth. Its value ranges from 0 to 1 and is shown in the figure. Solar insolation measures the amount of solar radiation, which is incident on the earth's surface. The average solar insolation of the selected site is $5.58 \mathrm{kWh} / \mathrm{m} 2 /$ day.

The data of wind resource for the selected site is also obtained from the National Aeronautics and Space Administration database of solar energy. Figure 6 shows the average wind speed data collected from the database. The left vertical axis indicates the average wind speed of the selected site and the horizontal axis represents the months of the selected year. The yearly average wind speed data is $4.2 \mathrm{~m} / \mathrm{s}$.



Figure 5. Solar radiation data

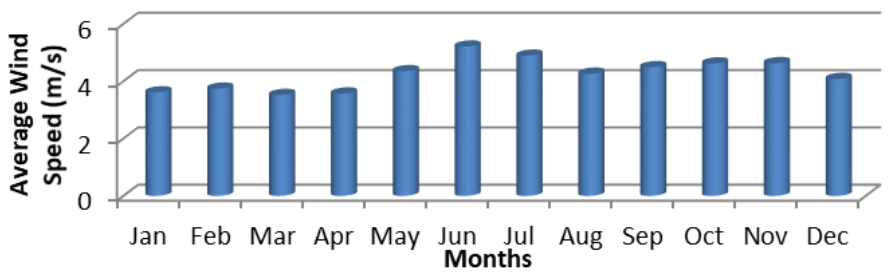

Figure 6. Wind speed data

\section{RESULTS AND DISCUSSION}

The BSA performs several repeated iterations and the optimum results can be seen from the final iteration. As can be seen from the iteration process, the most optimal, and efficient results are the design composed of solar photovoltaic cells, wind turbine, and battery. The last stages of the iteration process are shown in the table. A comparison of the results obtained from HOMER optimization [25], [26] and the proposed method is made and is given in the Table 3.

Table 3. Comparison of the results

\begin{tabular}{ccccccc}
\hline Method & No. of PV module & No. of wind turbine & No. of battery & Total Cost & D $_{\mathrm{L}}$ & LPSP \\
\hline Using HOMER & 758 & 0 & 2655 & 210000000 & Nil & Nil \\
Using BSA & 2276 & 7 & 1506 & 1794553 & 0.77 & 0.0 \\
\hline
\end{tabular}

Table 3 shows the results obtained from different optimization techniques. It can be seen that in reference to the HOMER model [27], [28], there is no scope for load satisfaction (LPSP) and utilizing the complementary characteristics of wind and solar $\left(\mathrm{D}_{\mathrm{L}}\right)$. But in the proposed method, because of full utilization of complementary characteristics of solar and wind, a smaller fluctuation of the output power is achieved. The proposed method guarantees a high-power supply reliability along with a lesser number of battery storage capacity.

\section{CONCLUSION}

An attempt is made to optimize the energy cost of particular area under consideration using HOMER and a powerful backtracking search algorithm (BSA). It is shown that the battery involvement is

Optimization of wind solar and battery hybrid renewable system using... (Ingudam Chitrasen Meitei) 
reduced with addition of solar panels (renewable). Optimization technique using BSA seems more promising, and found far better than done using HOMER. The total net present cost (NPC) comes out to be approximately Rs. 18 lakh with total saving of Rs 20 crore, advocating the huge savings with the proposed combinations of renewable sources. We obtain LPSP as zero, so it guarantees high power supply relaibilty.

\section{ACKNOWLEDGEMENT}

Authors of this paper highly acknowledged the management committee of MSPDCL, and manager of Shija Hospitals, Manipur.

\section{REFERENCES}

[1] B. Adebanji, G. A. Adepoju, P. Olulope, T. Fasina and O. Adetan, "Feasibility and optimal design of a hybrid power system for rural electrification for a small village," International Journal of Electrical and Computer Engineering (IJECE), vol. 10. no. 6, pp. 6214-6224, Dec. 2020, doi: 10.11591/IJECE.V10I6.PP6214-6224.

[2] C. Chompoo-Inwai, W. J. Lee, and P. Fuangfoo, "System impact study for the interconnection of wind generation and utility system," IEEE Trans. Ind. Appl., vol. 41, no. 1, pp. 1452-1458, Jan. 2005, doi: 10.1109/TIA.2004.841032.

[3] C. Phurailatpam, B. S. Rajpurohit, and L. Wang, "Planning and optimization of autonomous DC microgrid for rural and urban application in India," Renew. Sustain. Energy Rev., vol. 82, no. 1, pp. 198-204, Feb. 2018, doi: 10.1016/j.rser.2017.09.022.

[4] E. Planas, A. Gil-de-Murob, J. Andreu, I. Kortabarria, and I. M. de Alegría, "General aspects, hierarchical controls and droop methods in microgrids: a review," Renew. Sustain Energy Rev., vol. 17, pp. 147-159, Jan. 2013, doi: 10.1016/j.rser.2012.09.032.

[5] B. Fatima, C. Mama, and B. Benaissa, "Design methodology of smart photovoltaic plant," International Journal of Electrical and Computer Engineering (IJECE), vol. 11, no. 6, pp. 4718-4730, Jun. 2021, doi: 10.11591/ijece.v11i6.pp4718-4730.

[6] A. Woyte, V. Van, R. Belmans and J. Nijs, "Voltage fluctuations on distribution level introduced by photovoltaic systems," IEEE Trans. Energy Convers., vol. 21, no. 1, pp. 202-209, Mar. 2006, doi: 10.1109/TEC.2005.845454.

[7] L. O. Aghenta and M. T. Iqbal, "Design and Dynamic Modelling of a Hybrid Power System for a House in Nigeria," International Journal of Photoenergy, vol. 2019, pp. 1-13, Jul. 2019, doi: 10.1155/2019/6501785.

[8] J. B. Fulzele and Subroto Dutt, "Optimium Planning of Hybrid Renewable Energy System Using HOMER," International Journal of Electrical and Computer Engineering (IJECE), vol. 2, no. 1, pp. 68-74, Jan. 2012, doi: $10.11591 /$ ijece.v2i1.157.

[9] K. Rout and J. K. Sahu, "Various optimization techniques of hybrid renewable energy systems for power generation: a review," Int. Res. J. Eng. Technol. (IRJET), vol. 5, no. 7, Jul. 2018.

[10] A. Mohamed, Z. Abdelkader, and B. Abdelkrim, "Optimal configuration of hybrid PV- generator(Diesel/GPL) for a decentralized production of electricity in Algeria," International Journal of Power Electronics and Drive Systems (IJPEDS), vol. 11, no. 4, pp. 2038-2045, Dec. 2020, doi: 10.11591/ijpeds.v11.i4.pp2038-2045.

[11] D. E. Babatunde, O. M. Babatunde, M. U. Emezirinwune, I. H. Denwigwe, T. E. Okharedia, and O. J. Omodara, "Feasibility analysis of an off-grid photovoltaic-battery energy system for a farm facility," International Journal of Electrical and Computer Engineering (IJECE), vol. 10, no. 3, pp. 2874-2883, Dec. 2019, doi: 10.11591/ijece.v10i3.pp2874-2883.

[12] C. Chompoo-Inwai, W. J. Lee and P. Fuangfoo, "System impact study for the interconnection of wind generation and utility system," IEEE Trans. Ind. Appl., vol. 41, no. 1, pp. 1452-1458, Jan. 2005, doi: 10.1109/TIA.2004.841032.

[13] A. Woyte, V. Van, R. Belmans, and J. Nijs, "Voltage fluctuations on distribution level introduced by photovoltaic systems,” IEEE Trans. Energy Convers., vol. 21, no. 1, pp. 202-209, Mar. 2006, doi: 10.1109/TEC.2005.845454.

[14] R. Srivastava and V. K. Giri, "Optimization of hybrid renewable sources using HOMER," Int. J. Renew. Energy Res., vol. 6, no. 1, Jan. 2016.

[15] A. M. Yasin and M. F. Alsayed, "Fuzzy logic power management for a PV/wind microgrid with backup and storage systems," International Journal of Electrical and Computer Engineering (IJECE), vol. 11, no. 4, pp. 2876-2888, Jan. 2021, doi: 10.11591/ijece.v11i4.pp2876-2888.

[16] R. Chedid, H. Akiki, and S. Rahman, "A decision support technique for the design of hybrid solar-wind power system,” IEEE Trans. Energy Convers., vol. 13, no. 1, pp. 76-83, Mar. 1998.

[17] F. Ardakani, G. Riahy, and M. Abedi, "Optimal sizing of a grid-connected hybrid system for north-west of Irancase study," in Proc. IEEE EEEIC, pp. 29-32. Jun. 2010, doi: 10.1109/EEEIC.2010.5490006.

[18] M. Reyasudin Basir Khan, J. Pasupuleti, J. Al-Fattah and M. Tahmasebi, "Optimal grid-connected PV system for a campus microgrid," Indonesian Journal of Electrical Engineering and Computer Science (IJEECS), vol. 12, no. 3, pp. 899-906, Aug. 2018, doi: 10.11591/ijeecs.v12.i3.pp899-906.

[19] L. Xu, X. Ruan, C. Mao, B. Zhang, and Y. Luo, "An Improved Optimal Sizing Method for Wind Solar Battery Hybrid Power System," IEEE Trans. on Sustainable Energy, vol. 4, no. 3, Jul. 2013, doi: 10.1109/TSTE.2012.2228509. 
[20] P. Civicioglu, "Backtracking Search Optimization Algorithm for numerical ptimization problems," Applied Mathematics and Computation 219, vol. 219, no. 15, pp. 8121-8144. April 2013, doi: 10.1016/j.amc.2013.02.017.

[21] D. Menniti, A. Pinnarelli, and N. Sorrentino, "A method to improve microgrid reliability by optimal sizing PV/wind plants and storage systems," in Proc. IEEE CIRED, pp. 8-11. Jun. 2009, doi: 10.1049/cp.2009.1003.

[22] R. Chedid, H. Akiki and S. Rahman, "A decision support technique for the design of hybrid solar-wind power system,” IEEE Trans. Energy Convers., vol. 13, no. 1, pp. 76-83, Mar. 1998, doi: 10.1109/60.658207.

[23] J. Manwell and J. McGowan, "Lead acid battery storage model for hybrid energy systems," Solar Energy, vol. 50, no. 5, pp. 399-405, May 1993, doi: 10.1016/0038-092X(93)90060-2.

[24] J. F. Manwell et al., "HYBRID2-A hybrid system simulation model theory manual," Dep. Mechan. Eng., Univ. Mass., Renewable Energy Research Lab., Jan. 1999.

[25] I. C. Meitei, A. K. Irungbam, B. A. Shimray, "Performance evaluation of hybrid renewable energy system for supplying electricity to an institute and a hospital using HOMER," International Conference on Intelligent Computing and Smart Communication, pp. 1317-1326, Jan. 2020, doi: 10.1007/978-981-15-0633-8_129.

[26] I. C. Meitei, T. B. Singh, K. Denish, H. H. Meitei, and N. A. Singh, "Optimum design of photovoltaic system for a medical institute using HOMER," International conference on intelligent computing and smart communication, pp, 1337-1346, Jan. 2020, doi: 10.1007/978-981-15-0633-8_131.

[27] I. C. Meitei and R. Pudur, "Analysis and Optimization of Hybrid Renewable Energy Sources: A Case Study for Litan, Manipur," Journal of Advance Research in Dynamic and Control Systems, vol. 12, no. 3, pp. 200-208, March 2020, doi: 10.5373/JARDCS/V12SP3/20201254.

[28] A. Gheiratmand, R. Effatnejad, and M. Hedayati, "Technical and economic evaluation of hybrid wind/pv/battery systems for off-grid areas using HOMER software," International Journal of Power Electronics and Drive Systems (IJPEDS), vol. 7, no. 1, pp. 134-143, Jan. 2016, doi: 10.11591/ijpeds.v7.i1.pp134-143.

\section{BIOGRAPHIES OF AUTHORS}
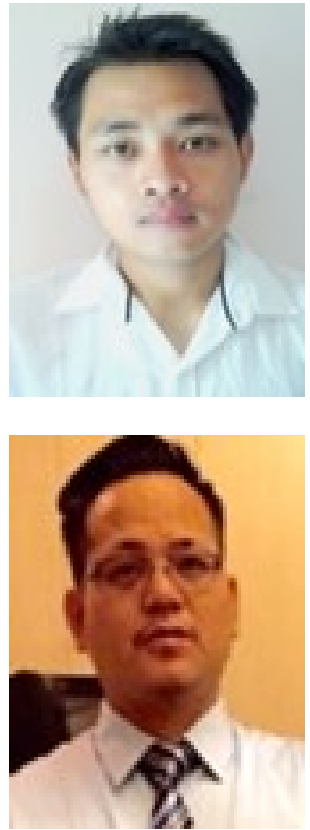

Ingudam Chitrasen Meitei, completed B.E. in Electrical Engineering from Saurashtra University (2010) and M.Tech from Anna University (2015) and started his teaching carrier from 2015. He is currently working as a Lecturer in EE dept. of National Institute of Technology Manipur, Imphal, India and also pursuing PhD. in the dept. of EE of NIT Arunachal pradesh. His area of interest is Electrical Machines and Renewable Energy.

Rajen Pudur, received his Ph.D (2016) and M.Tech (2011) from the NERIST, Arunachal Pradesh. From 2004 to 2007, he was working as a Guest Lecturer in NERIST From 2008 to 2012, he was working as a Junior Engineer. Since 2012, he has been working as an Assistant professor in NIT Arunachal Pradesh in Electrical Engineering Deoartment. His area of interest is Power system, renewable sources of energy, power quality issues, micro hydro power plant, renewable energy integration and SEIG for rural areas. 